\title{
Brenda R. Weber: \\ Makeover TV. Selfhood, Citizenship and Celebrity. Durham \& London: Duke University Press. 2009.
}

\author{
Anne Jerslev
}

MedieKultur 2010, 49, 201-204

Published by SMID | Society of Media researchers In Denmark | www.smid.dk The online version of this text can be found open access at www.mediekultur.dk

In her absolutely to be recommended book about makeover TV, American professor of gender studies at Indiana University Brenda Weber cites a female participant in Extreme Makeover, a rancher, for lamenting, "I do the job of a man. I've never been the bell of the ball. I've never stopped traffic when I walked into a room. I've never had every eye on me". Weber uses the remark to illustrate one of her main arguments about makeover TV, that the show works to construct a normative femininity which is not polluted by signifiers of masculinity. But the melodramatic enunciation also points to the fairy tale narrative underpinning this reality show about ordinary women (and men) undergoing an outer and inner transformation. I mean - who has had everyone's eye on you? And it points to the gendered rationale of the transformation. Being the sought after brand-new me is not least about spectacular "being-seen-ness" as "a necessary aspect of normative femininity and femaleness" (p. 132). But the improvement also manifests as an ability to scrutinise oneself, a valuable capacity for self-surveillance.

The show regards the woman's excessive wish as absolutely legitimate. And many of the shows are excessive stagings of transformations from misery to magic me. However, paradoxically, the whole point of Extreme Makeover and a range of the great majority of makeover/life style shows Weber has examined is to release participants from the dysfunctionalities of emotional and bodily excess which constitute their social and bodily Before. It is in a sense to construct rational and functional, unambiguously gendered subjects, consumers and citizens. The ritualised travel occurs from Before to After, which typically runs 
through six phases: initial shaming of the participant as the subject of misery, surveillance by audience and experts, the surrender to the makeover by the participant, the transformation, the spectacle of the reveal, and the final "euphoria of the new-and-improved subject and satisfied experts" (p. 31) transports participants from shame and suffering over surrender and surveillance to salvation. Thus, the six phases form a kind of "quasi-religious narrative" (p. 31). In the last spectacular part of the makeover narrative, unsuitable excess has been detached from the participant's everyday body and social life and transformed into the glamorous and luxurious wrapping of the new, well-groomed feminine commodity body. The made over body is "a naturally strong and youthful body, fueled by internal self-confidence and marked by earning capacity and heterosexual allure" (p. 196). Therefore, Weber argues, beauty is not what the shows primarily call for, but beauty is a necessary means to the acquisition of self-esteem, confidence and, ultimately, the transformation into the epitome of a good citizen-consumer in a neo-liberal society. As such, Weber's take on makeover TV is in line with newer understandings of reality TV (by Laurie Ouellette and James Hay, and Gareth Palmer most notably) as a kind of contemporary citizenship training, laboratories of conduct, and, hence, a contribution to the mediatisation of everyday life. Thus, the book's first chapter elaborates at length on the ways the makeover shows articulate values of Americanness and ideals of citizenship, whereas the following three analyse the ways the makeover subject develops capacities to conform to economies of looking and gender. Finally, the last chapter situates makeover shows within a broader culture of celebrification. Weber here looks at the ways makeover shows spectacular scenarios of reveal borrow from celebrity culture aesthetics and how this is in accordance with the shows' underlying logic. Despite the participants' often expressed wishes to be just normal, "the makeover's goal is less about being normal than being normative, residing not in an actual body but in an imagined body" (p. 255).

The containment of excess through its transformation into stylish spectacularity is one example of the many thematic paradoxes Weber lays out in her readings of the genre's construction and negotiation of gender and subjectivity. She argues convincingly that displacement is one way of maintaining an idea of egalitarianism (albeit "a color-blind egalitarianism" (p. 132)). Each participant is equally qualified for the empowerment the makeover produces. Each story of misery is individual and specific and thus not related to larger patterns of class, race or gender. As such, race is displaced by style and beauty, and class by glamour and celebrification.

Weber focuses mainly on textual constructions of femininity - but also masculinity in the book's fourth chapter, where especially Queer Eye for the Straight Guy is scrutinised. However, she also takes issue with reading positions and the pleasures of watching makeover shows. Weber eloquently discusses how the shows may construct different, even contradictory, meanings; how the makeover logic, despite its normative view of gender, also contains "positive" or "emancipatory possibilities". No doubt, Weber's well-written and wellresearched book adds to the body of scholarly works on the televisual makeover takeover, 
which has primarily consisted of articles regarding single shows (for example my own article about the cosmetic surgery makeover show The Swan in New Review of Film and Television Studies (2008)). The strength of her book lies in the critical demonstrations of the textual displacements and dissolution of complex questions of gender and subjectivity into simple and unambiguous ones. However, despite her interest in different reading positions, phrases like "This message of salvation through submission" (p. 6), "its message of redemption and transformation" (p. 258) and "makeover shows communicate messages of gender regulation that instruct viewers [...](p. 207) (my italics) run through her book. Thus, two different views of texts as communication collide in the book.

According to Annette Hill and Caroline Dover's analysis of makeover television audiences in Makeover Television. Realities Remodelled (2007) - which Weber refers to in a note - message is not necessarily received by viewers - or even viewed as messages. Makeover television is looked upon as light entertainment. Viewers may get ideas concerning contemporary trends (in clothes, interior decoration, body grooming etc.) but do not necessarily follow them. Weber on the other hand seems to practice a kind of ideology analysis. At least the term ideology is used on numerous occasions: "The ideological theme" (of change and improvement (p. 29)), "The makeover's ideologies evince a deep cultural desire for a coherent celebrated self" (p. 257), "The makeover's ideology requires that it traffic in a teleology form bad to good" (p. 137), "other ideological apparatuses at work in the makeover's gender politics" (p. 131). The question remains however what she actually means by ideology and how she relates this reading to possible "emancipatory" readings. Is ideology synonymous with critical text analysis? Could she just as well have used concepts like "textual operations", "rhetorical operations", and "discourses" (a term she also uses on numerous occasions)? Maybe. But I do think her way of using ideology to emphasise the makeover show as a powerful and unambiguously gendered textual system blocks the way for the more cogent analytical defence of the show she also intends to put forward. I am not implying that her analytical method is old fashioned. But I guess the broader question her 'ideological critical' analysis poses is: How is it methodologically possible to make empirical studies of the ways audiences give meaning to texts and critical analyses of ideology, that is, the powerful persuasive working of popular cultural messages fruitfully illuminating each other.

On the one hand, Weber argues that the show constructs a normative femininity as ideal. On the other hand, she also sympathises with the way the makeover shows' construction of empowered womanhood may appeal to an audience. Her way of bridging the gap between the critical text analysis and the genre's widespread popularity is - in accordance with critical traditions for reading popular cultural texts - to regard the makeover shows as dream scenario, "a fantasy about gender and simplicity" (p. 159). The transformation's final outcome is textually unambiguous: After constitutes a stable, heterosexual gendered human being. This very lack of ambiguity might be one of the reasons for the show's popularity she contends. It offers a stable and authentic, that is normative, womanhood as the normal. In the dream scenario, gender poses no problem. Even though the makeover 
is regarded as a technology of empowerment in some scholarly works, Weber notes that there is certain nostalgia concerning the idea of femininity as unequivocally defined. And even if participants seek empowerment, "that very power is conferred only through the male gaze" (p. 166) in the shows. Thus, gender is never a process, a continuous performance or negotiation. Normative femininity (and masculinity) is in a sense there from the beginning, only the makeover is necessary to release it from its prison in a body of misery. This is another of the paradoxes Weber outlines; in order to "communicate an "authentic self", one must overwrite and replace the "false" signifiers enunciated by the natural body" ( $p$. 4). The Before body is the socially "marked" body; the makeover "unmarks" it, adjusts it in accordance with normative femininity. The made over body is not only the normative and normal body but also the natural body. This is yet another paradox: "the makeover doesn't create but brings out one's inner woman. Looking like a woman thus paradoxically creates and expresses one's already present, but previously blocked, womanhood" (p. 128).

"Everyone loves a good transformation", wrote the New York Times journalist Anita Gates in 2005 in an article about the 23 different home makeover programs shown on US TV channels at that time. A good transformation follows the happy narrative from misery to redemption, which Weber outlines in her book. It is a story about progress and improvement. A good transformation creates a skilled consumer and confident citizen. The madeover participant is citizen in Makeover Nation, a term Weber borrows from the title of Toby Miller's book from 2008 about the ways contemporary US embodies the American Dream of transformation, progress and improvement or, in Miller's words: self-invention via commodities. In Weber's reading of the construction of gender in makeover television, this is a reactionary tale of progress. The genre constructs a clipped citizen, a makeover subject "not made to engage in public sphere discourses but to circulate as public sphere spectacles" (p. 261). And yet, Weber likes the genre and she proposes that it is liked because "it offers a site of hope" (p. 263). But then, what does she do with the uncomfortable results of her analysis? She seems to think that they can work together. However, her book does not really convince me of that.

Anne Jerslev

Professor

Department of Media, Cognition and Communication

University of Copenhagen, Denmark jerslev@hum.ku.dk 